\title{
PEMBELAJARAN FISIKA BERBASIS NATURE OF SCIENCE (NOS) UNTUK MENINGKATKAN PEMAHAMAN KONSEP FISIKA PESERTA DIDIK
}

\author{
Purwoko Haryadi Santoso ${ }^{1, a}$, Mutmainna ${ }^{1, b}$ \\ ${ }^{1}$ Program Studi Pendidikan Fisika, Fakultas Keguruan dan Ilmu Pendidikan, Universitas Sulawesi Barat \\ e-mail: ${ }^{\text {p}}$ purwokoharyadisantoso@unsulbar.ac.id, ${ }^{\mathrm{b}}$ mutmainna_kadir@unsulbar.ac.id
}

\begin{abstract}
Abstrak
Pemahaman tentang NOS pada peserta didik tidak hanya bermanfaat terhadap kemampuan literasi peserta didik, tetapi juga dapat meningkatkan pemahaman konsep fisika peserta didik. Akan tetapi, masih kurangnya penelitian yang mendalam yang menganalisis hubungan antara pembelajaran NOS dengan hasil belajar fisika peserta didik. Artikel ini menyajikan suatu rencana penelitian yang berisi tentang kerangka teori, desain, dan metode penelitian untuk menguji apakah pembelajaran NOS dapat membantu peserta didik dalam konsep fisika yaitu usaha dan energi. Ada tiga kelas yang dirancang untuk menerima tiga jenis pembelajaran. Kelompok pertama menerima pembelajaran NOS yang tidak dikontekstualkan dan dilanjutkan dengan materi usaha dan energi. Sedangkan, kelompok kedua hanya menerima pembelajaran usaha dan energi tanpa melibatkan diskusi tentang NOS secara langsung. Kelompok ketiga menerima pembelajaran NOS terintegrasi dengan materi usaha dan energi. Setelah mengalami pembelajaran, peserta didik mengikuti pre-dan post-test tentang materi NOS dan usaha energi, serta peserta didik juga diwawancarai untuk menganalisis apakah dan bagaimana mereka menggunakan pemahaman tentang NOS untuk mempelajari fisika.
\end{abstract}

Kata kunci: pembelajaran fisika, nature of science, NOS, pemahaman konsep

\section{NATURE OF SCIENCE (NOS) BASED PHYSICS INSTRUCTION TO ENHANCE STUDENT'S CONCEPTUAL UNDERSTANDING}

\begin{abstract}
Student's understanding of NOS was not only to foster their literacy ability, but also to improve their conceptual understanding in physics. However, there was still inadequate research analyzing the relationship between NOS-oriented learning and student achievement in physics. This artible will provide a research plan include theoretical framework, study design, and research method to investigate if NOS aspects could improve the student's understanding in work and energy concept. There was three designed classes to experienced three lessons. The first class receive NOS content which is not contextualized and continued by leaning work and energy directly. Meanwhile, the second class just receive work and energy concept directly, they didn't learn NOS aspects in class. The third class had NOS learning integrated with concept of work and energy. After learning executed, students take the pre-and post-test abot NOS aspects and work-energy concepts, as well as they were intervied to analyze if and how they used their understanding to study physics
\end{abstract}

Keywords: physics learning, nature of science, NOS, conceptual understanding

\section{PENDAHULUAN}

Nature of science (NOS) telah lama diperkenalkan sebagai sebuah konsep penting dalam pendidikan sains (Lederman, 2007). Fisika termasuk ke dalam ilmu sains yang juga harus memahami konsep pembelajaran NOS ini. Konsep pembelajaran NOS telah diinternalisasikan ke dalam beberapa dokumen standar pendidikan di beberapa negara bagian Amerika Serikat (contohnya AAAS, 1993; National Research Council, 1996; NGSS Lead States, 2013); McComas \& Olson, 1998). Selain memandang bahwa konsep pembelajaran NOS adalah penting terhadap 
kemampuan literasi sains peserta didik, praktisi dan peneliti dalam pendidikan juga telah menemukan bahwa pembelajaran berbasis NOS harus diterapkan di sekolahsekolah. Dengan memahami NOS atau hakikat sains diharapkan dapat meningkatkan kualitas pembelajaran fisika yaitu dengan merenungkinkan dan menghubungkan antara konsep fisika dan bagaimana sejarah konsep fisika itu bisa ditemukan (Driver et al, 1996). Akan tetapi, pernyataan bahwa "asumsi ini [...] belum secara sistematis diuji secara luas" (Lederman, 2007) masih valid hingga hari ini (Peters, 2012). Penelitian yang telah dilakukan bertujuan untuk melakukan penyelidikan ini dan untuk menganalisis hbungan antara pembelajaran NOS dan peningkatan pemahaman konsep fisika peserta didik, khususnya pada konsep energi.

\section{NATURE OF SCIENCE (NOS) DAN KONTEN PEMBELAJARAN FISIKA}

Referensi pendidikan fisika dan ilmu pendidikan menyampaikan terdapat banyak faktor yang berperan penting dalam pemahaman konsep fisika peserta didik, termasuk motivasi diri, minat, dan konsep diri terhadap fisika (Cavallo et al, 2003; Deci \& Ryan, 1985; Leibham et al, 2013), dan juga keyakinan epistemologi (Cavallo et al, 2003; Tsai, 1998). Keyakinan epistemologi sangat erat kaitannya dengan NOS, meskipun Hogan (2000) menyarankan agar kita membedakan diantara keduanya dalam perspektif penelitian pendidikan fisika. Keyakinan epistemologi merupakan "pemahaman seseorang tentang pengetahuan dan mengetahui" (Mason \& Bromme, 2010), sedangkan NOS merupakan "bagaimana fisika bisa ada, fisika sebagai pola pikir, atau nilai-nilai dan pemahaman yang berhubungan dengan konsep fisika atau proses pengembangan ilmu fisika" (Lederman, 2004). Secara jelas, terdapat hal yang tumpang tindih antara NOS dan keyakinan epistemologi (Hogan, 2000: Lederman, 2007), oleh karena itu, dengan memahami lebih dalam hubungan antara NOS dan pembelajaran konsep fisika termasuk melakukan kajian pustaka terkait peran keyakinan epistemologi peserta didik.

Pengaruh keyakinan epistemologi terhadap pembelajaran fisika telah diteliti oleh Yang \& Tsai (2012). Beberapa bukti empirik menyimpulkan bahwa terdapat pengaruh keyakinan epistemologi terhadap strategi pembelajaran peserta didik (Tsai, 1998), tujuan pembelajaran mandiri (Cavallo, et al, 2003), keterampilan beralasan dan menyatakan pendapat (Bell \& Linn, 2000), dan kemampuan metakognitif (Tsai, 1998). Secara keseluruhan, pengaruh aspek keyakinan epistemologis ini memperoleh nilai yang tinggi pada aspek yang berhubungan dengan aspek-aspek NOS. Pengaruh NOS dalam pembelajaran telah diteliti yaitu terdapat pengaruh positif terhadap kemampuan pemecahan masalah (Lin \& Chiu, 2004) dan kemampuan beralasan. Semua kemampuan ini dapat membantu peserta didik dalam memahami konsep fisika. Dengan demikian, dapat diasumsikan bahwa dengan memahami NOS, peserta didik dapat mengikuti pembelajaran fisika dengan lebih baik.

\section{PEMBELAJARAN NOS YANG EFEKTIF}

Meskipun pemahaman NOS terbukti merupakan faktor penting yang mempengaruhi proses pembelajaran, peserta didik dan guru fisika masih belum memiliki pemahaman NOS yang baik (Abd-ElKhalick \& Lederman, 2000; Dogan \& AbdEl-Khalick, 2008; Ibrahim et al., 2009; Khishfe \& Abd-El-Khalick, 2002). 
Pendekatan pembelajaran NOS secara "implisit", dimana konten fisika dan keterampilan proses dilaksanakan peserta didik dengan cara peserta didik melaksakan eksperimen tanpa melakukan refleksi terhadap aktivitas yang telah mereka lakukan. Pendekatan "implisit" seperti ini hanya memiliki pengaruh kecil terhadap pemahaman peserta didik terhadap NOS (Khishfe \& Abd-El-Khalick, 2002). Selain itu, pendekatan ini akan beresiko menyebabkan peserta didik memiliki dua pemahaman tentang inkuiri ilmiah. Pertama, pemahaman mereka berdasarkan pengalaman sehari-hari dan yang mereka peroleh melalui media. Kedua, pemahaman yang mereka hubungkan dengan pengalaman yang diperoleh di sekolah. Hal ini terjadi ketika peserta didik tidak menyadari aktivitas mereka sebagai aktivitas "ilmiah" (Clough, 2006; Solomon, 1991). Untuk memicu internalisasi cara berpikir peserta didik dan untuk membuat mereka memperdalam pembelajaran NOS maka harus diterapkannya pendekatan pembelajaran yang bersifat "eksplisitreflektif'. Pendekatan ini dirancang untuk mengarahkan perhatian peserta didik terhadap pentingnya aspek-aspek NOS dalam pembelajaran (Akerson et al., 2000; Bell et al., 2000; Clough, 2006; Khishfe \& Abd-El-Khalick, 2002; Lederman, 2007). Hal ini dapat diperoleh dengan mengajarkan aspek-aspek NOS secara "eksplisit" kepada peserta didik sebelum mereka mengikuti pendekatan pembelajaran saintifik. Selain itu, peserta didik merefleksikan dan membandingkan bagaimana aktivitas mereka terhadap aktivitas ilmuan "sebenarnya" (Akerson, et al, 2010).

Metode yang biasanya digunakan dalam melaksanakan pembelajaran NOS secara eksplisit adalah dengan menjelaskan aspek-aspek NOS dengan atau tanpa melibatkan konsep fisika yang terlibat (Lederman \& Abd-El-Khalick, 1998). Aktivitas pembelajaran yang tidak kontekstual seperti ini tidak akan terserap oleh peserta didik karena mereka tidak memiliki perasaan lebih dekat dengan konsep fisika yang dipelajari. Hal ini akan menyebabkan dua pemahaman seperti yang sudah dijelaskan di paragraf sebelumnya (Clough, 2006). Selain itu, guru mungkin hanya memandang kegiatan berorientasi NOS hanya sebagai "pelengkap" pembelajaran, yang akan lebih terfokus dalam menyampaikan konsep-konsep fisika secara langsung yang dianggap guru adalah lebih penting (Lakin \& Wellington, 1994). Untuk mengatasi permasalahan ini dan menciptakan pembelajaran NOS yang sebenarnya, aspek-aspek NOS harus disisipkan dalam pembelajaran secara kontekstual (Brickhouse et al., 2000; Schwartz \& Crawford, 2004). Jika pemahaman NOS dan konsep fisika tergabung dengan baik, peserta didik dapat mengkaitkan pengalaman hidupnya dengan keterampilan proses yang dilakukan. Selain itu, guru tidak akan menganggap bahwa implementasi pembelajaran NOS hanya menghabiskan waktu pembelajaran saja.

Untuk memperkenalkan aspek-aspek NOS kepada peserta didik, guru harus merancang pembelajaran kontekstual dimana konten NOS harus dihubungkan dengan konten fisika yang akan didiskusikan. Hubungan ini tidak harus dibuat secara terburu-buru, tetapi dapat diawali dengan menyampaikan aspek NOS dan konten fisika secara terpisah. Hal ini dilakukan untuk mencegah terjadinya pemahaman peserta didik yang menyimpang terkait aspek-aspek NOS dan konsep fisika dalam waktu yang sama (Leach, et al, 2003). 
Kemudian, pembelajaran NOS secara kontekstual dapat dilaksanakan melalui metode inkuiri terbimbing, diskusi kelompok, eksperimen, atau dengan mengkaji kasus sejarah fisika (Akerson, et al, 2010; Clough, 2006).

Akan tetapi, pembelajaran yang berorientasi NOS masih jarang diterapkan (Scwartz, 2013). Contohnya, Peters (2012) menemukan bahwa pembelajaran berorientasi NOS dapat memfasilitasi peserta didik dalam memahami konsep fisika pada materi listrik dan magnet. Di sisi lain, pengaruh keyakinan epistemologi dan NOS terhadap pencapaian peserta didik belum begitu jelas hasilnya. Contohnya, Cavallo, et al (2003) menemukan pengaruh keyakinan epistemologi secara langsung dalam pembelajaran pada mata pelajaran biologi, tetapi tidak ditemukan dalam pembelajaran fisika. Secara berlawanan, Schwartz (2013) tidak menemukan hubungan antara pemahaman NOS peserta didik terhadap konsep biologi sama sekali.

Kesimpulannya, hubungan antara pembelajaran berorientasi NOS dan pemahaman konsep peserta didik masih belum jelas. Penelitian terapan tambahan harus dilakukan untuk mencari apakah proses pembelajaran bisa terbantu dengan menginternalisasi pemahaman NOS kepada peserta didik. Khususnya, bagaimana peran pembelajaran NOS (kontekstual atau tak kontekstual) terhadap pemahaman aspek NOS peserta didik dan konsep fisika peserta didik. Sebagian besar penelitian mengukur keyakinan epistemologi dan pemahaman NOS sebagai variabel capaian pembelajaran. Pemahaman NOS dijadikan tujuan pembelajaran penting atau sebagai variabel kontrol. Akan tetapi, untuk menyelidiki pengaruh pembelajaran berorientasi NOS terhadap proses pembelajaran kita harus memperhatikan perubahan pemahaman NOS yang terjadi dalam diri peserta didik selama intervensi dilakukan. Serta, untuk menguji bagaimana peserta didik menggunakan pemahaman ini untuk menemukan konsep fisika dalam pembelajaran.

\section{TUJUAN PENELITIAN}

Penelitian ini bertujuan untuk menganalisis pengaruh pembelajaran berorientasi NOS terhadap pemahaman peserta didik pada konsep fisika dan aspekaspek NOS. Rumusan hipotesis penelitian ini antara lain : (1) pembelajaran NOS berpengaruh positif terhadap pemahaman konsep peserta didik, (2) pembelajaran NOS yang kontekstual lebih berpengaruh positif terhadap pemahaman NOS dan konsep fisika daripada pembelajaran yang hanya menyampaikan konsep fisika saja atau pembelajaran NOS yang tidak kontekstual terhadap konsep fisika yang didiskusikan.

\section{METODE}

\section{Desain Penelitian}

Penelitian ini menggunakan pendekatan kuantitatif dengan perlakuan pada kelas eksperimen dan kelas kontrol. Kelompok eksperimen terdiri dari 3 kelas masing-masing berisi 40 peserta didik. Hipotesis 1 diuji dengan membandingkan kelompok eksperimen 1 dan kelompok 2, keduanya memperoleh tiga kali pembelajaran pada materi usaha dan energi. Kelompok 1 memperoleh pembelajaran usaha energi dengan terlebih dahulu dijelaskan aspek-aspek NOS. Kelompok 2 memperoleh pembelajaran langsung atau sering disebut juga dengan metode konvensional. Untuk menguji hipotesis 2 dibutuhkan kelompok 3 yang menerima enam kali pembelajaran usaha energi yang berorientasi NOS yang dikontekstualkan 
(Clough, 2006). Pada kelompok ini terjadi perpaduan antara NOS dan konsep usaha energi secara lebih mendalam. Setelah itu, kelompok 3 dibandingkan dengan kelompok 2, dimana kelompok 2 mendapatkan 3 kali pembelajaran tambahan. Pembelajaran menghabiskan waktu sebanyak 90 menit dan diatur dalam suasana laboratorium di luar ruangan.

\section{Kelompok 1}

\begin{tabular}{|c|c|c|c|c|}
\hline & $\begin{array}{c}\text { Pembelajaran NOS } \\
\text { secara langsung }\end{array}$ & & Kelompok 2 & Kelompok 3 \\
\hline \multirow[t]{2}{*}{ NOS, KF >> } & |-----------------. & & ------------------------ & ----------- \\
\hline & $\begin{array}{c}\text { Pembelajaran Usaha } \\
\text { \& Energi }\end{array}$ & & $\begin{array}{c}\text { Pembelajaran } \\
\text { Usaha \& Energi }\end{array}$ & Pembelajaran \\
\hline NOS, KF >> & --------------------------- & $\mathrm{KF}$ & $\begin{array}{c}\text { Pembelajaran } \\
\text { Usaha \& Energi }\end{array}$ & $\begin{array}{l}\text { yang } \\
\text { Terintegrasi }\end{array}$ \\
\hline
\end{tabular}

NOS, KF

NOS, KF >>

Gambar 1. Desain Penelitian dengan 3 Kelas Eksperimen. Garis putus-putus menunjukkan tes yang akan dilaksanakan $(\mathrm{NOS}=$ Nature of Science, $\mathrm{KF}=$ Konsep Fisika $)$

\section{Desain Intervensi}

Dua kelas yang menerima pembelajaran yang berorientasi NOS dilakukan secara tak dikontekstualkan dan dengan dikontekstualkan seperti yang dilaksanakan oleh Clough (2006). Pada kelas 1, pembelajaran NOS dilakukan dengan menyajikan aspek-aspek NOS secara langsung sebelum pembelajaran konsep fisika (Lederman \& Abd El Khalick, 1998) dan selanjutnya mendiskusikannya, tanpa menghubungkan aspek-aspek NOS dengan konsep usaha dan energi. Maka, peserta didik dapat fokus untuk bertanya dan berpendapat secara kritis, yang dapat menjadi tugas yang menantang bagi peserta didik, tanpa diganggu dengan memikirkan hubungannya dengan konten fisika. Sebaliknya, kelas 3 menerima pembelajaran NOS yang diintegrasikan dengan konten usaha dan energi. Papadouris dan Constantinou (2011; 2014) menjelaskan pendekatan pembelajaran secara filosofis pada materi usaha energi, termasuk kegiatan pembelajaran yang dihubungkan dengan eksperimen fisika, serta diskusi mendalam dan merefleksikan tentang pentingnya aspek-aspek NOS dalam mempelajari fisika. Pada pembelajaran NOS, kegiatan ini dibersamakan juga dengan mempelajari sejarah studi kasus. Aspek-aspek NOS ditekankan pada dua hal yaitu (1) perbedaan antara proses mengamati dan mengambil kesimpulan, dan (2) hakikat teori fisika yang bersifat tentatif, karena aspekaspek ini dianggap paling penting dalam memahami konsep usaha dan energi. Tujuan pembelajaran ini adalah agar peserta didik dapat memandang konsep energi sebagai kerangka teori yang telah ditemukan, diuraikan, dan diperbaiki sepanjang sejarah untuk menjelaskan berbagai macam fenomena alam.

Materi pembelajaran usaha energi dipelajari oleh ketiga kelas dalam penelitian ini. Secara khusus, terdapat 4 aspek materi energi yang dianggap penting dalam pembelajaran, yang sering diajarkan dengan urutan yaitu: (1) sumber dan bentuk energi, (2) perpindahan dan perubahan energi, 
kehilangan energi, dan (4) pelestarian energi (Duit, 2013; Neumann, et al, 2013). Pada pelaksanaan pembelajaran, eksperimen dan kegiatan pembelajaran diarahkan pada kegiatan mengeksplorasi sebuah taman bermain (theme park). Permainan seperti rollercoaster, bungee jumping, dan "bumpbump car" digunakan untuk memperkenalkan dan menjelaskan bentuk energi kinetik dan potensial serta proses perubahan energi pada permainan di atas. Beberapa kegiatan dan eksperimen diampil dari kurikulum IQWST yaitu dengan memperimen pendekatan eksperimen hands-on tentang pelestarian energi (Fortus, et al, 2012). Kelompok 1, yang telah menerima pembelajaran NOS secara langsung di awal pembelajaran, dan kelas 2 menerima tiga kali pembelajaran pada materi usaha energi yang tidak memasukkan konten pembelajaran NOS. Kemudian, kelas 2 kemudian menerima pembelajaran energi tambahan, termasuk kegiatan untuk mengulangi dan memperdalam materi sebelumnya. Untuk kelas 3, aspek-aspek NOS terdistribusi dalam pembelajaran materi usaha energi (contohnya seperti Constantinou \& Papadouris, 2012; Papadouris \& Constantinou, 2011; Papadouris \& Constantinou, 2014).

Kesimpulannya, intervensi yang dilakukan dalam penelitian ini melaksanakan pembelajaran yang sama tujuannya dan materinya tentang usaha energi, serta metode pembelajaran yang sama, dan yang berbeda hanyalah cara untuk memasukkan konten NOS dalam pembelajaran.

\section{Teknik Pengumpulan Data}

Sebelum dan setelah pelaksanaan pembelajaran, peserta didik diminta untuk mengisi kuesioner tentang pemahaman mereka terhadap aspek-aspek NOS dan tentang pemahaman peserta didik pada konsep usaha energi. Pemahaman peserta didik pada NOS dinilai dengan instrumen tes pilihan majemuk
NOSSI yang dikembangkan oleh Neumann (2011) dan soal open ended VNOS-C yang dikembangkan oleh Abd-El-Khalick (1998). Kedua tes ini dilaksanakan sebelum dan setelah materi pembelajaran. Dilaksanakan sebelum pembelajaran adalah untuk menguji bagaimana pemahaman peserta didik tentang NOS. Kemudian dilaksanakan setelah pembelajaran untuk mengetahuai peningkatan pemahaman peserta didik terkait NOS.

Selanjutnya, penilaian pemahaman peserta didik pada konten fisika usaha energi juga menggunakan tes pilihan majemuk dan open ended, yang fokus kepada pengetahuan deklaratif dan terintegrasi pada materi energi dan tentang hakikat energi sebagai konsep fisika. Baik tes pemahaman NOS dan konsep fisika tidak hanya menekankan aspek-aspek yang disampaikan dalam pembelajaran, tetapi juga aspek-aspek tambahan yang mungkin harus diperoleh peserta didik di luar pembelajaran. Hal ini dilakukan untuk menyelidiki apakah peserta didik telah mengembangkan pemahaman mendalam dari aspek-aspek yang didiskusikan secara implisit di dalam kelas. Selain itu, post-tesi juga akan melibatkan evaluasi terhadap motivasi peserta didik, telah dibuktikan bahwa membuktikan pengatuh pemahaman peserta didik pada NOS terhadap variabel ini (Clough, 2011). Selama enam minggu setelah eksperimen ini adalah penilaian follow-up terhadap pemahaman peserta didik terhadap NOS dan energi untuk menguji perbedaan kemampuan peserta didik dalam waktu yang lama.

Selain itu, beberapa peserta didik yang menjadi subyek penelitian pada kelompok 1 dan 3 (yang menerima pembelajaran NOS) juga akan diwawancarai. Hal dilakukan untuk memperoleh informasi yang lebih dalam ketika dan bagaimana peserta didik menggunakan pemahaman NOS mereka untuk mempelajari konten fisika. 


\section{SIMPULAN DAN SARAN}

\section{Simpulan}

Penelitian ini bertujuan untuk menganalisis hubungan antara pembelajaran NOS dan pemahaman konsep fisika peserta didik. Penelitian ini menyelidiki apakah dan bagaimana NOS harus diajarkan untuk meningkatkan pemahaman peserta didik setelah mengalami pembelajaran. Hasil penelitian ini mungkin tidak hanya memberikan wawasan pembelajaran NOS dan konsep fisika, tetapi juga dapat menginformasikan guru tentang pentingnya untuk melibatkan pemahaman NOS dalam pembelajaran untuk membantu peserta didik dalam pembelajaran. Meskipun, pembelajaran NOS belum secara eksplisit menjadi bagian dalam kurikulum dan standar pendidikan di Indonesia sekarang.

\section{Saran}

Penulis berharap pembaca artikel ini dapat menerapkan metode penelitian yang telah dirancang dalam proses pengambilan data di lapangan. Hal ini dikarenakan artikel ini baru menginformasikan rancangan penelitian yang kedepannya akan dilaksanakan.

\section{DAFTAR PUSTAKA}

[1] Lederman, N. G. (2007). Nature of science: Past, present, and future. In S. K. Abell \& N. G. Lederman (Eds.), Handbook of research on science education. Mahwah, N.J: Lawrence Erlbaum Associates.

[2] American Association for The Advancement Ok Science (AAAS). (1993). Benchmarks for Science Literacy, Oxford, New York: Oxford University Press.

[3] National Research Council. (1996). National science education standards. National Academies Press.

[4] NGSS Lead States. 2013. Next Generation
Science Standards: For States, By States. Washington, DC: The National Academies Press.

[5] McComas, W. F., \& Olson, J. K. (1998). The nature of science in international science education standard documents. In W. F. McComas (Ed.), The Nature of science in science education. Rationales and strategies (pp. 41-52). Dordrecht: Kluwer Academic Publishers.

[6] Driver, R., Leach, J., Millar, R., \& Scott, P. (1996). Young people's images of science. Buckingham: Open Univ. Press.

[7] Peters, E. E. (2012). Developing content knowledge in students through explicit teaching of the nature of science: Influences of goal setting and selfmonitoring. Science \& Education, 21(6), 881-898

[8] Cavallo, A. M., Rozman, M., Blickenstaff, J., \& Walker, N. (2003). Learning, reasoning, motivation, and epistemological beliefs. Journal of College Science Teaching, 33, 18-23.

[9] Deci, E. L., \& Ryan, R. M. (1985). Intrinsic motivation and selfdetermination in human behavior. Perspectives in social psychology. New York: Plenum.

[10] Leibham, M. B., Alexander, J. M., \& Johnson, K. E. (2013). Science interests in preschool boys and girls: Relations to later self-concept and science achievement. Science Education, 97(4), 574-593

[11] Tsai, C.-C. (1998). An analysis of scientific epistemological beliefs and learning orientations of Taiwanese eighth graders. Science Education, 82, 473-489.

[12] Hogan, K. (2000). Exploring a process view of students' knowledge about the nature of science. Science Education, 84, 51-70.

[13] Mason, L., \& Bromme, R. (2010). Situating and relating epistemological beliefs into metacognition: studies on beliefs about knowledge and knowing. Metacognition and Learning, 5(1), 1-6

[14] Lederman, N. G. (2004). Syntax of nature of science within inquiry and science instruction. In L. B. Flick \& N. G. 
Lederman (Eds.), Science \& technology education library: Vol. 25. Scientific inquiry and nature of science (pp. 301317). Dordrecht: Springer.

[15] Yang, F.-Y., \& Tsai, C.-C. (2012). Personal epistemology and science learning: A review on empirical studies. In B. J. Fraser, K. G. Tobin, \& C. J. McRobbie (Eds.), Second international handbook of science education (pp. 259280). Dordrecht: Springer.

[16] Bell, P., \& Linn, M. C. (2000). Scientific arguments as learning artifacts: designing for learning from the web with KIE. International Journal of Science Education, 22(8), 797-817

[17] Lin, H.-s., \& Chiu, H.-L. (2004). Student understanding of the nature of science and their problem-solving strategies. International Journal of Science Education, 26(1), 101-112

[18] Abd-El-Khalick, F. S., \& Lederman, N. G. (2000). Improving science teachers' conceptions of nature of science: a critical review of the literature. International Journal of Science Education, 22(7), 665701

[19] Dogan, N., \& Abd-El-Khalick, F. S. (2008). Turkish grade 10 students' and science teachers' conceptions of nature of science: A national study. Journal of Research in Science Teaching, 45(10), 1083-1112

[20] Ibrahim, B., Buffler, A., \& Lubben, F. (2009). Profiles of freshman physics students' views on the nature of science. Journal of Research in Science Teaching, 46(3), 248-264

[21] Khishfe, R., \& Abd-El-Khalick, F. S. (2002). Influence of explicit and reflective versus implicit inquiry-oriented instruction on sixth graders' views of nature of science. Journal of Research in Science Teaching, 39(7), 551-578

[22] Clough, M. P. (2006). Learners' responses to the demands of conceptual change: Considerations for effective nature of science instruction. Science \& Education, 15(5), 463-494

[23] Solomon, J. (1991). Teaching about the nature of science in the british national curriculum. Science Education, 75(1), 95103

[24] Akerson, V. L., Abd-El-Khalick, F. S., \& Lederman, N. G. (2000). Influence of a reflective explicit activity-based approach on elementary teachers' conceptions of nature of science. Journal of Research in Science Teaching, 37(4), 295-317.

[25] Bell, R. L., Lederman, N. G., \& Abd-ElKhalick, F. S. (2000). Developing and acting upon one's conception of the nature of science: A follow-up study. Journal of Research in Science Teaching, 37(6), 563581.

[26] Akerson, V. L., Weiland, I., Pongsanon, K., \& Nargund, V. (2010). Evidence-based strategies for teaching nature of science to young children. Journal of Kirsehir Education Faculty, 11(4), 61-78.

[27] Lederman, N. G., \& Abd-El-Khalick, F. (1998). Avoiding de-natured science: activities that promote understandings of the nature of science. In W. F. McComas (Ed.), The Nature of science in science education. Rationales and strategies (pp. 83-126). Dordrecht: Kluwer Academic Publishers.

[28] Lakin, S., \& Wellington, J. (1994). Who will teach the 'nature of science'?: teachers' views of science and their implications for science education. International Journal of Science Education, 16(2), 175-190

[29] Brickhouse, N. W., Dagher, Z. R., Letts, W. J., \& Shipman, H. (2000). Diversity of Students' Views about Evidence, Theory, and the Interface between Science and Religion in an Astronomy Course. Journal of Research in Science Teaching, 37(4), 340-362.

[30] Schwartz, R. S., \& Crawford, B. A. (2004). Authentic Scientific Inquiry as a Context for Teaching Nature of Science: Identifying Critical Elements for Success. In L. B. Flick \& N. G. Lederman (Eds.), Science \& technology education library: Vol. 25. Scientific inquiry and nature of science (pp. 331-355). Dordrecht: Springer. 
[31] Leach, J., Hind, A., \& Ryder, J. (2003). Designing and evaluating short teaching interventions about the epistemology of science in high school classrooms. Science Education, 87(6), 831-848

[32] Schwartz, R. S. (2013). Impacts of explicit/reflective nature of science instruction in the context of an undergraduate biology course. Paper presented at the NARST annual conference, Rio Grande, Puerto Rico.

[33] Peters, E. E. (2012). Developing content knowledge in students through explicit teaching of the nature of science: Influences of goal setting and selfmonitoring. Science \& Education, 21(6), 881-898

[34] Cavallo, A. M., Rozman, M., Blickenstaff, J., \& Walker, N. (2003). Learning, reasoning, motivation, and epistemological beliefs. Journal of College Science Teaching, 33, 18-23.

[35] Papadouris, N., \& Constantinou, C. P. (2011). A philosophically informed teaching proposal on the topic of energy for students aged 11-14. Science \& Education, 20(10), 961-979

[36] Papadouris, N., \& Constantinou, C. P. (2014). An Exploratory Investigation of 12-Year-Old Students' Ability to Appreciate Certain Aspects of the Nature of Science through a Specially Designed Approach in the Context of Energy. International Journal of Science Education, 36(5), 755-782

[37] Duit, R. (2013). Teaching and Learning the Physics Energy Concept. Retrieved from http://esummitmsu.net/content/teaching-and-learningphysics-energy-concept

[38] Neumann, K., Viering, T., Boone, W. J., \& Fischer, H. E. (2013). Towards a learning progression of energy. Journal of Research in Science Teaching, 50(2), 162188

[39] Fortus, D., Abdel-Kareem, H., Chen, J., Forsyth, B., Grueber, D. J., Nordine, J., \& Weizman, A. (2012). Why do some things stop while others keep going? In J. S. Krajcik, B. J. Reiser, D. Fortus, \& L. M.
Sutherland (Eds.), Investigating and

[40] Neumann, I. (2011). Beyond physics content knowledge: Modeling competence regarding nature of scientific inquiry and nature of scientific knowledge. Berlin: Logos.

[41] Abd-El-Khalick, F. S. (1998). The influence of history of science courses on students' conceptions of nature of science (Unpublished doctoral dissertation). Oregon State University, Corvallis.

[42] Clough, M. P. (2011). The Story Behind the Science: Bringing Science and Scientists to Life in Post-Secondary Science Education. Science \& Education, 20(7-8), 701-717 